\title{
Chemical composition and antioxidant activity of essential oils isolated from Colombian plants
}

\author{
Jesús Olivero-Verbel, ${ }^{* 1,2}$ Tulia González-Cervera, ${ }^{1}$ Jorge Güette-Fernandez, ${ }^{1}$ \\ Beatriz Jaramillo-Colorado, ${ }^{1,2}$ Elena Stashenko ${ }^{2}$
}

\author{
${ }^{1}$ Environmental and Computational Chemistry Group. Faculty of Pharmaceutical Sciences. Campus of Zaragocilla. \\ University of Cartagena. Cartagena, Colombia, \\ ${ }^{2}$ Chromatography Laboratory, Research Centre of Excellence, Cenivam, Industrial University of Santander, \\ Building 45, Bucaramanga, Colombia.
}

\begin{abstract}
RESUMO: "Composição química e atividade antioxidante de óleos essenciais isolados de plantas da Colombia." Treze óleos essenciais de plantas da Colômbia, obtido por hidrodestilação ou hidrodestilação assistida por microondas, da planta inteira, caule, folhas e flores, foram analisados por técnicas de espectrometria de massa acoplada a cromatografia gasosa. Foi avaliada a citotoxicidade de óleos essenciais utilizando o ensaio com Artemia salina e suas atividades antioxidantes medindo seus efeitos sobre os níveis de substâncias reativas ao ácido tiobarbitúrico em microssomas de fígado de rato induzida por $\mathrm{Fe}^{2+} / \mathrm{H}_{2} \mathrm{O}_{2}$. Cinco óleos apresentaram alta citotoxicidade $(\mathrm{LC} 50<10 \mu \mathrm{g} / \mathrm{mL}$ ) sobre o ensaio de Artemia salina. A atividade antioxidante do óleo essencial de Ocotea sp., Tagetes lucida e Lippia alba (quimiotipo geranial) apresentaram os menores valores de Concentração Eficaz (CE50), na ordem de 31,1, 37,9 e 94,9 $\mu \mathrm{g} / \mathrm{mL}$, respectivamente. Os principais componentes desses óleos foram $\alpha$-pineno (42\%), estragol $(95,7 \%)$ e geranial $(30,4 \%)$, respectivamente. Elettaria cardamomum e Lippia alba (quimiotipo carvona, Tolima) apresentaram moderada atividade antioxidante com valores de CE50 de 130,5 e 174,4 $\mu \mathrm{g} / \mathrm{mL}$, respectivamente. Os óleos essenciais de mollis Minthostachys mollis, Lippia alba (quimiotipo carvona, Cundinamarca), e Piper sanctifelisis não mostraram atividade antioxidante (CE50>1000 $\mu \mathrm{g} / \mathrm{mL})$.
\end{abstract}

Unitermos: Óleo essencial, hidrodestilação, atividade antioxidante, TBARS, citotoxicidade, Colombia.

\begin{abstract}
Thirteen essential oils from Colombian plants, obtained by hydrodistillation or microwave-assisted hydrodistillation of total plant, stem, leaves, and flowers were analyzed by gas-chromatography-mass spectrometry techniques. Cytotoxicity of essential oils was assessed using the brine shrimp assay, and their antioxidant activities measuring their effects on the levels of thiobarbituric acid reactive substances on rat liver microsomes induced by $\mathrm{Fe}^{2+} / \mathrm{H}_{2} \mathrm{O}_{2}$. Five oils showed high cytotoxicity ( $\mathrm{LC} 50<10 \mu \mathrm{g} / \mathrm{mL}$ ) on the brine shrimp assay. The antioxidant activity of the essential oil from Ocotea sp., Tagetes lucida and Lippia alba (geranial chemotype) showed the lowest mean effective concentrations (EC50), with values of 31.1, 37.9 and $94.9 \mu \mathrm{g} / \mathrm{mL}$, respectively. The main components for these oils were $\alpha$-pinene (42\%), estragole (95.7\%) and geranial (30.4\%), respectively. Elettaria cardamomum and Lippia alba (carvone chemotype, Tolima) presented moderate antioxidant activities with EC50 values of 130.5 and $174.4 \mu \mathrm{g} / \mathrm{mL}$, respectively. Essential oils from Minthostachys mollis, Lippia alba (carvone chemotype, Cundinamarca), and Piper sanctifelisis did not show antioxidant activity (CE50>1000 $\mu \mathrm{g} / \mathrm{mL})$.
\end{abstract}

Keywords: Essential oil, hydrodistillation, antioxidant activity, TBARS, Cytotoxicity, Colombia.

\section{INTRODUCTION}

Essential oils are natural products with many applications and demand in the food, perfumery, cosmetics, pharmaceutical and winery industries, among others (Arbujarai \& Natsheh, 2003; Ajose, 2007; Natsch $\&$ Wasescha, 2007; Fisher, 2008). These complex mixtures have different pharmacological properties, including anti- inflammatory (Tabanca et al., 2007; Tekeoglu, 2007), antibacterial (Ravishankar et al., 2008; Sharififar et al., 2007), antifungal (Farzaneh et al., 2006), protective of the gastrointestinal tract (Monteiro et al., 2007), anticonvulsant (Viana et al., 2000) and antioxidant properties (SafaeiGhomi et al., 2009; Li et al., 2007; Magwa et al., 2006). This last characteristic makes these chemicals suitable as food preservatives, as the free radical oxidation of the lipid 
components in these products is a major strategic problem for manufacturers (Pokorny et al., 2001). A number of synthetic antioxidants such as butylated hydroxyanisole (BHA) and the related compound butylated hydroxytoluene (BHT) are currently used in food processing (Soarez et al., 2003; Henderson \& Slickman, 1999). However, these compounds are known by their capability of promoting tumor formation (Malkinson et al., 1997). Thus, the search for new, natural, and low toxicity antioxidants is extensive, and numerous compounds have been tested using a diversity of methodologies (Ruberto et al., 2000; Kulisic et al., 2004). However, much remains to be clarified about how they exert their antioxidant properties, although it has been suggested that some have the ability to trap radicals (Foti \& Ingold, 2003).

Despite the fact that Colombia has an immense biodiversity, few studies have been reported on the biological properties of essential oils from plants that grow in this country. The aim of this work was to determine the composition of essential oils from plants collected in different regions of this country, and to evaluate their cytotoxicity and antioxidant activity in a lipid peroxidation model using rat liver homogenates.

\section{MATERIAL AND METHODS}

\section{Plant material collection and treatment}

Thirteen plants of six different families (Gramineae, Labiateae, Magnoliaceae, Piperaceae, Verbenaceae, and Zingiberaceae) were collected at several regions of Colombia (Antioquia, Arauca, Bolívar, Boyacá, Chocó, Cundinamarca, Nariño, and Tolima. Undamaged plants (stems, leaves, flowers) were transported to the Cenivam Laboratory at the Industrial University of Santander, Bucaramanga (Colombia). Species were identified by botanists from the Institute of Natural Sciences at the National University of Colombia (Bogotá); specimen voucher numbers were assigned to each one (Table 1), and deposited at the National Herbarium. Permission to collect these samples was given by the Colombian Housing and Environment Ministry.

\section{Essential oil extraction and analysis}

Oils from collected plants were obtained from different parts (total plant, stem, and combination of leaves and flowers) by hydrodistillation (HD) and microwaveassisted hydrodistillation (MWHD) (Table 1). HD was performed in a $5 \mathrm{~L}$ round flash with $500 \mathrm{~g}$ of plant material and $4 \mathrm{~L}$ of water, using an electric heater (boiling water) for $2 \mathrm{~h}$. The oil was decanted from the condensate, previously saturated with $\mathrm{NaCl}$, and dried with anhydrous sodium sulfate, as described elsewhere (Stashenko et al., 2004a,b). On the other hand, for the MWHD, the hydrodistillation apparatus was placed inside a domestic microwave oven
(2.45 GHz, $800 \mathrm{~W})$ with a side orifice through which an external glass condenser joined the round flask with the plant material $(500 \mathrm{~g})$ and water $(0.2 \mathrm{~L})$, inside the oven. The oven was operated for $30 \mathrm{~min}$ at full power, which caused water to boil vigorously and reflux. Essential oil was decanted from the condensate and dried with anhydrous sodium sulfate.

Essential oil analyses were performed using an Agilent Technologies 6890 Plus equipped with a HP-5 MS capillary column $\left(30 \mathrm{~m} \times 0.25 \mathrm{~mm}\right.$ i.d. $\left.\times 0.25 \mu \mathrm{m}, \mathrm{d}_{\mathrm{f}}\right)$ and an Agilent Technologies MSD 5973 mass-selective detector. For gas chromatography-mass spectrometry detection, an electron ionization system with ionization energy of $70 \mathrm{eV}$ was used. Helium was the carrier gas at a flow rate of $1 \mathrm{~mL} /$ min. Injector and MS transfer line temperatures were set at 220 and $290{ }^{\circ} \mathrm{C}$, respectively. Column temperature was initially at $50^{\circ} \mathrm{C}$, and then gradually increased to $150{ }^{\circ} \mathrm{C}$ at a $3{ }^{\circ} \mathrm{C} / \mathrm{min}$ rate, held for $10 \mathrm{~min}$, and finally raised to 250 ${ }^{\circ} \mathrm{C}$ at $10{ }^{\circ} \mathrm{C} / \mathrm{min}$. Diluted samples $\left(1: 100 \mathrm{v} / \mathrm{v}\right.$, in $\left.\mathrm{CH}_{2} \mathrm{Cl}_{2}\right)$ of $1.0 \mu \mathrm{L}$ were injected manually and in the Splitless mode. The components were identified on the basis of comparison of their relative retention time and mass spectra with those of some standard compounds, NBS75K library data of the GC-MS system, and literature data (Adams, 1995; Davies, 1990).

\section{Cytotoxicity assays}

The essential oil acute toxicity (mean lethal concentration) (LC50) was evaluated using the brine shrimp (Artemia franciscana) assay as described elsewhere (D'Souza et al., 2002; Massele, 1995). Briefly, $10 \mathrm{mg}$ of dried brine shrimp eggs (Great Lake, Salt Lake City, UT, USA) were deposited in fresh filtered seawater and allowed to hatch for $24 \mathrm{~h}$. The assay was performed dissolving the essential oil in DMSO at a maximum concentration of 1.3 $\% \mathrm{v} / \mathrm{v}$. Ten larvae were put in $10 \mathrm{~mL}$ seawater containing the essential oil at concentrations between 0.01 and 1000 $\mu \mathrm{g} / \mathrm{mL}$. The LC50 assay was done using three replicates for each concentration, and counting of dead organisms was carried out 24 and $48 \mathrm{~h}$ after exposure to the different essential oil concentrations. All the experiments were conducted by quadruplicates and LC50 values as well as 95\% confidence intervals were calculated using the Probit method (Finney, 1971).

\section{Antioxidant assay using the thiobarbituric acid reactive species (TBARS) method}

The essential oil antioxidant effects were tested by measuring their ability to inhibit the formation of TBARS, including malondialdehyde (MDA), induced by Fe (II) and $\mathrm{H}_{2} \mathrm{O}_{2}$ in rat liver tissues (Kade et al., 2008; Oliveira et al., 2006). This assay quantifies the peroxidation of polyunsaturated fatty acids (PUFA) present in liver microsomal fraction. Male Wistar rats $(298 \pm 6.5 \mathrm{~g})$ were

\begin{tabular}{r|l} 
& \\
\hline Rev. Bras. Farmacogn. & \multirow{2}{*}{569} \\
Braz. J. Pharmacogn. & \\
20(4): Ago./Set. 2010 &
\end{tabular}


decapitated under mild ether anesthesia and hepatic (liver) tissues were rapidly dissected, placed on ice and weighed. Tissues were immediately homogenized in ice cold saline solution $(0.15 \mathrm{M} \mathrm{KCl}, \mathrm{pH} 7.4)$, maintaining a relationship of $100 \mathrm{mg}$ of liver per each $0.9 \mathrm{~mL}$ of $\mathrm{KCl}$, with 10 up-and-down strokes at approximately $1200 \mathrm{rev} /$ min in a Teflon-glass homogenizer. The homogenate was centrifuged for $10 \mathrm{~min}$ at $1600 \mathrm{~g}$ at $4{ }^{\circ} \mathrm{C}$ to yield a pellet and a low-speed supernatant, followed by centrifugation of the supernatant at $20000 \mathrm{~g}$ for another $10 \mathrm{~min}$ at $4{ }^{\circ} \mathrm{C}$. The resulted supernatant extract was used as liver homogenate (Yildirim et al., 2000). Peroxidation of liver homogenate was induced by addition of $\mathrm{FeCl}_{2}(0.1 \mathrm{mM})$ and $\mathrm{H}_{2} \mathrm{O}_{2}(3$ $\mathrm{mM}$ ) (Oliveira et al., 2006; Zhang et al., 2001).

Each essential oil was dissolved in the homogenate to obtain final concentrations of $0.1,1,10$ and $100 \mu \mathrm{g} /$ $\mathrm{mL}$, in a final volume of $500 \mu \mathrm{L}$ (fraction $\mathrm{S} 10$ with $\mathrm{FeCl}_{2}$ and $\mathrm{H}_{2} \mathrm{O}_{2}$ ), incubated at $37 \pm 1{ }^{\circ} \mathrm{C}$ during $1 \mathrm{~h}$, and then centrifuged at $5000 \mathrm{~g}$ for $5 \mathrm{~min}$ at $25^{\circ} \mathrm{C}$. After incubation, lipid peroxidation in the supernatant was determined by rapid addition of $2.5 \mathrm{~mL}$ TCA-TBA reagent $(15 \% \mathrm{w} / \mathrm{v}$ trichloroacetic acid, TCA, and $0.375 \%$ thiobarbituric acid, TBA) to the reaction mixture, incubated at $95{ }^{\circ} \mathrm{C}$ for $60 \mathrm{~min}$ in a boiling water bath, and after cooling, the precipitated flocculent was removed by centrifugation at $20000 \mathrm{~g}$ for $5 \mathrm{~min}$ at $25^{\circ} \mathrm{C}$. Absorbance of TBARS in the supernatant was recorded at $540 \mathrm{~nm}$ against a blank containing all the reagents (Haraguchi et al., 1997). TBARS concentration was normalized to protein content. Butylated hydroxytoluene (BHT) $(2.5 \mu \mathrm{g} / \mathrm{mL})$ was used as standard antioxidant and dimethyl sulfoxide (DMSO) was utilized as vehicle control (Kulisic, 2004). The results were expressed as nmoles of $\mathrm{MDA} / \mathrm{mg}$ protein. Each essential oil was assayed by triplicate.

\section{Statistical analysis}

The results were expressed as mean \pm S.D. Significant differences between means for different oil concentrations were analyzed by ANOVA using Dunnet test as a post-test. In all cases, normal distribution and equality between standard deviations were evaluated using Kolmogorov-Smirnov and Barlett test, respectively. In absence of normality comparison between concentrations were carried out by Kruskal Wallys. Differences between groups were considered significant at $p<0.05$.

\section{RESULTS AND DISCUSSION}

\section{Chemical composition of essential oils}

The major compounds of the essential oils analyzed by GC-MS are presented in Table 2. These compounds are mainly hydrocarbons, oxygenated monoterpenes and oxygenated sesquiterpenes. It is clear that the composition of the essential oil of Lippia alba depends on the collection site and the corresponding chemotype. The main constituents of Lippia alba (VEmtT01E, VEmtT02E and VEmcT02E) were carvone, limonene and bicyclosesquiphellandrene. However, in Lippia alba VEboW02E, the main components were geranial and neral, wheras for Lippia alba VEsrW01E were

Table 1. Taxonomical classification, geographical collection and extraction type for analyzed essential oils.

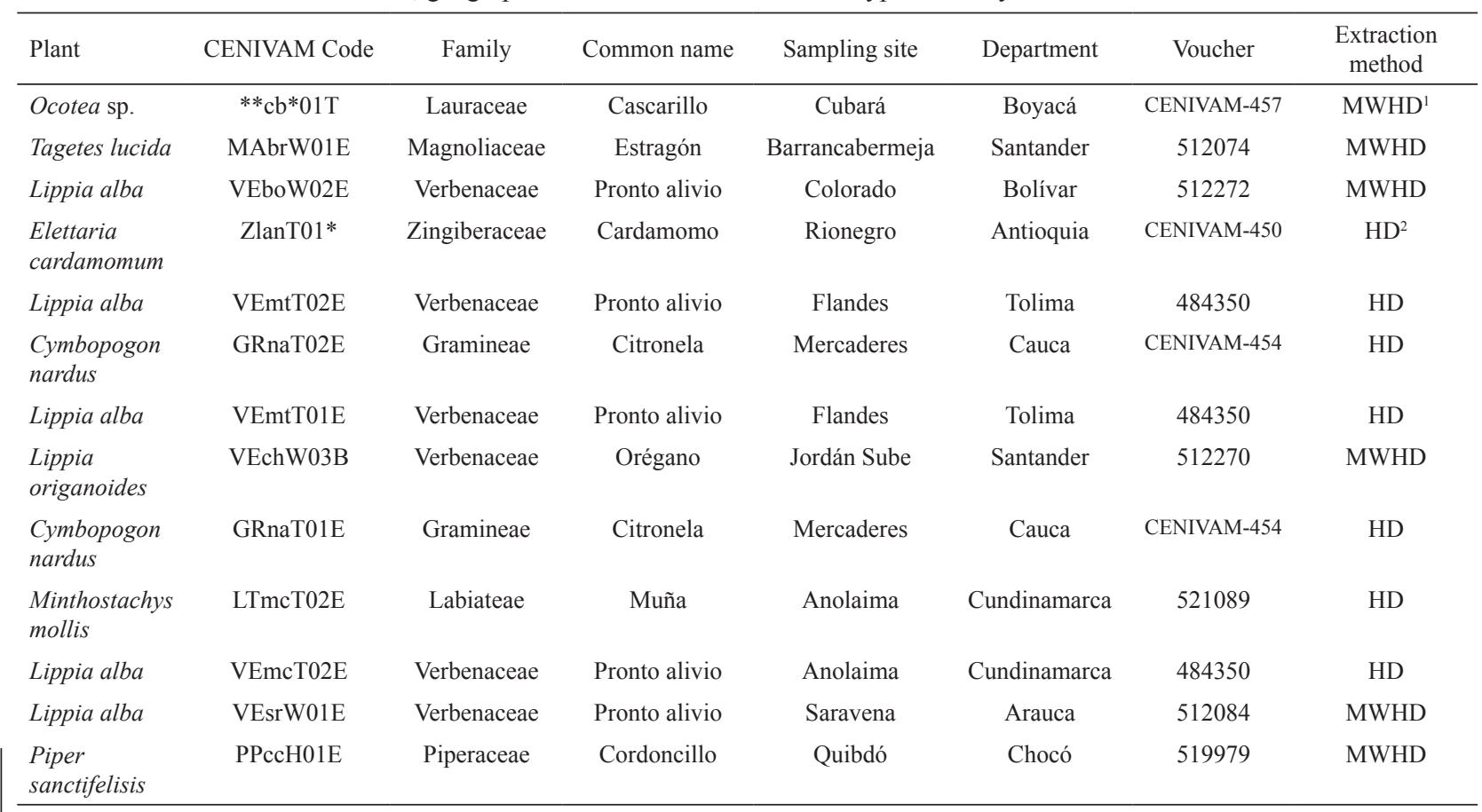

1. MWHD, Microwave-assisted hydrodistillation; 2. HD, Hydrodistillation

Samples with vouchers named CENIVAM are stored in our herbarium in Bucaramanga 
Table 2. Major constituents identified and quantified in the studied essential oils.

\begin{tabular}{|c|c|}
\hline Essential Oil & Major components \\
\hline Minthostachys mollis (LTmcT02E) & $\begin{array}{l}\text { Pulegone (19\%), trans- } \beta \text {-caryophyllene (18\%), menthone (11.9\%), bicyclogermacrene (11.3\%), germacrene } \\
\text { D (11\%) }\end{array}$ \\
\hline Ocotea sp. $\left(* * \mathrm{cb}^{*} 01 \mathrm{~T}\right)$ & $\alpha$-Pinene (42\%), p-cymene (14.6\%), $\beta$-pinene (12.7\%) \\
\hline Elettaria cardamomum (ZIanT01*) & 1,8-Cineol (29.7\%), $\alpha$-terpineol acetate $(26.1 \%)$ \\
\hline Cymbopogon nardus (GRnaT02E) & Citronellal (42.1\%), geraniol (14.9\%) \\
\hline Cymbopogon nardus (GRnaT01E) & Citronellal (30.7\%), geraniol (16.9\%), citronellol (12.1\%) \\
\hline Lippia alba (VEmtT01E) & Bicyclosesquiphellandrene (35.9\%), carvone (24.5\%), limonene (14.7\%) \\
\hline Lippia alba (VEmtT02E) & Bicyclosesquiphelandrene (27.4\%), carvone (26.9\%), limonene (18.6\%) \\
\hline Lippia alba (VEmcT02E & Carvone (25.5\%), bicyclosesquifelandrene (27.4\%), limonene (20.6\%) \\
\hline Lippia alba (VEboW02E) & Geranial (30.4\%), neral (23.9\%), trans- $\beta$-caryophyllene ( $8 \%)$ \\
\hline Tagetes lucida (MAbrW01E) & Estragole $(95.7 \%)$ \\
\hline Lippia origanoides (VEchW03B) & $p$-Cymene (15.7\%), trans- $\beta$-caryophyllene (9.4\%), $\alpha$-terpinene $(6.9 \%)$ \\
\hline Piper sanctifelisis (PPccH01E) & $\alpha$-terpinene (35.3\%), bicyclogermacrene (7.1\%), trans- $\beta$-caryophyllene ( $5 \%)$ \\
\hline Lippia alba (VEsrW01E) & Carvone (25.3\%), cis- $\beta$-ocimene (22.4\%), neral (10.4\%), geranial (10.4\%) \\
\hline
\end{tabular}

carvone, cis- $\beta$-ocimene and neral. Although quantitative differences are verified, the composition of the essential oils of Lippia alba shows agreement with the existence of different chemotypes as previously described (Bounatirou et al., 2007; Oliveira et al., 2006; Zoghbi et al., 1998).

The principal components of Ocotea sp. were $\alpha$-pinene (42\%), $p$-cymene (14.6\%), and $\beta$-pinene $(12.7 \%)$. This composition is different from that found for Ocotea quixos (Ishpingo) from Ecuador, oil that has transcinnamaldehyde $(27.9 \%)$ and methyl cinnamate $(21.7)$ as major constituents (Bruni et al., 2004). Ishpingo essential oil differs from commercially exploited $O$. pretios $a$ and $O$. cymbarum oils () by the absence of both methyleugenol and safrole. In particular, the absence of safrole allows only minor constraints on the use of Ecuadorian Ishpingo essential oil (due to the recognized toxicity of this compound) (Ioannides et al., 1981). More than 350 species belong to the Ocotea genus, mainly distributed in the Americas and in Southern Africa, and those are widely known as commercial sources of spicy essential oils.

Estragole (95.7\%) was the major constituent in the essential oil of Tagetes lucida from Colombia. This plant is an aromatic herb distributed naturally in Central and South America, where it is used as a spice, for medicinal purposes, as insecticide, and as ornamental plant. The essential oil obtained from this species cultivated in Costa Rica has methyl chavicol (95-97\%) as a major component (Cicció, 2004).

The main components found in the volatile oil from Colombian Elettaria cardamomum were 1,8-cineol (29.7\%) and $\alpha$-terpineol acetate (26.1\%). In contrast, Marongiu et al. (2004) found as majority compounds in E. cardamomun $\alpha$-terpinyl acetate (42.3\%), 1,8-cineole $(21.4 \%)$, linalyl acetate $(8.2 \%)$, limonene (5.6\%), and linalool (5.4\%). Regarding the other studied species, major constituents for Minthostachys mollis were pulegone, mentone and trans- $\beta$-caryophyllene; for
Cymbopogon nardus were citronellal and geraniol; for Lippia origanoides: p-cymene, trans- $\beta$-caryophyllene, $\alpha$-terpinene; and for Piper sanctifelisis: $\alpha$-terpinene (35.3\%), bicyclogermacrene $(7.1 \%)$,trans- $\beta$-caryophyllene (Table 2).

\section{Cytotoxicity of essential oils against Artemia franciscana}

The LC50 of the essential oils based on the brine shrimp assay after 24 and $48 \mathrm{~h}$ exposure are presented in Table 3. Values varied between $4.36-64.3 \mu \mathrm{g} / \mathrm{mL}$ and $1.2-$ $20.8 \mu \mathrm{g} / \mathrm{mL}$, for 24 and $48 \mathrm{~h}$ exposure, respectively. These results, although indicate that most tested essential oils can be considered cytotoxic ( $\mathrm{LC} 50<10 \mu \mathrm{g} / \mathrm{mL}$ ), also pointed out that that bioactivity is highly dependent on chemotype, type of extraction and sampling location (Medina-Holguín et al., 2008).

The ratio of the estimated LC50s (24 h-LC50/48 h-LC50) for Ocotea sp., Piper sanctifelisis, Elettaria cardamomum, Lippia alba (VEboW02E) and Cymbopogon nardus ranged between 1.03 and 1.69. This indicates that an increase in the exposure time from 24 to $48 \mathrm{~h}$ does not lead to a marked augment in toxicity, suggesting that naupliar susceptibility to these essential oils do not change throughout development. However, time-dependent larvae development was highly susceptible to essential oils obtained from Minthostachys mollis and Lippia alba (chemotype carvone, Tolima), with LC50 ratios of 9.43 and $5.91 \mu \mathrm{g} / \mathrm{mL}$.

In general, it has been suggested that the cytotoxic activity of essential oils is mostly due to the presence of phenols, aldehydes and alcohols (Bruni et al., 2004; Sacchetti et al., 2005, Oliveira et al., 2006). 
Table 3. Cytotoxicity against Artemia franciscana and antioxidant capacity of essential oils.

\begin{tabular}{|c|c|c|c|c|}
\hline Essential oils (Code) & LC50-24 h $(\mu \mathrm{g} / \mathrm{mL})$ & $\mathrm{LC} 50-48 \mathrm{~h}(\mu \mathrm{g} / \mathrm{mL})$ & LC50-24 h/LC50-48 h & $\begin{array}{l}\text { Antioxidant activity } \\
\left(\mathrm{CE}_{50}\right)(\mu \mathrm{g} / \mathrm{mL})\end{array}$ \\
\hline Piper sanctifelisis (PPccH01E) & $4.36(4.84-3.92)$ & $3.27(3.64-2.93)$ & 1.33 & $>000$ \\
\hline Lippia alba (VEmtT01E) & $4.53(5.41-3.79)$ & $1.17(1.47-0.94)$ & 3.86 & $331.6(291.5-377.2)$ \\
\hline Lippia alba (VEsrW01E) & $6.95(8.03-6.03)$ & $2.42(2.83-2.06)$ & 2.88 & $>1000$ \\
\hline Ocotea sp. Cascarillo $\left(* * \mathrm{cb}^{*} 01 \mathrm{~T}\right)$ & $7.84(8.32-7.39)$ & $7.59(8.88-6.48)$ & 1.03 & $31.1(27.9-34.7)$ \\
\hline Lippia alba (VEmcT02E) & $8.14(9.39-7.05)$ & $2.21(2.83-1.72)$ & 3.68 & $>1000$ \\
\hline Cymbopogon nardus (GRnaT02E) & $12.41(13.70-11.24)$ & $4.61(5.60-3.86)$ & 2.67 & $309.8(264.8-362.5)$ \\
\hline Lippia origanoides (VEchW03B) & $14.41(15.61-13.30)$ & $5.08(5.82-4.44)$ & 2.84 & $463.5(408.1-526.4)$ \\
\hline Cymbopogon nardus (GRnaT01E) & $19.73(20.77-18.75)$ & $11.66(12.72-10.68)$ & 1.69 & $860.5(730.0-1014.4)$ \\
\hline Lippia alba (VEboW02E) & $21.05(22.58-19.63)$ & $15.21(16.63-13.90)$ & 1.38 & $94.9(82.6-109.0)$ \\
\hline Minthostachys mollis (LTmcT02E) & $21.29(25.04-18.11)$ & $2.26(2.71-1.88)$ & 9.43 & $>1000$ \\
\hline Tagetes lucida (MAbrW01E) & $22.14(23.54-20.82)$ & $17.68(19.03-16.42)$ & 1.25 & $37.9(34.5-41.6)$ \\
\hline Elettaria cardamomum (ZIanT01*) & $27.79(29.42-26.26)$ & $20.83(22.54-19.26)$ & 1.33 & $130.5(115.8-147.2)$ \\
\hline Lippia alba (VEmtT02E) & $64.33(68.05-60.82)$ & $10.88(14.12-8.38)$ & 5.91 & $174.4(152.0-200.0)$ \\
\hline Butylated hydroxytoluene, BHT $(5 \mu \mathrm{M})$ & & & & $55.22 \%(52.49-57.95)^{a}$ \\
\hline
\end{tabular}

${ }^{a}$ Antioxidant activity exhibited by $5 \mu \mathrm{M}$ BHT, calculated as the percentage inhibition of MDA production when compared to control.

\section{Antioxidant activity of essential oils}

The ability of the Colombian essential oils to act as antioxidant in the TBARS assay is presented in Table 3. CE50 values varied between $31.1 \mu \mathrm{g} / \mathrm{mL}$ and $>1000 \mu \mathrm{g} /$ $\mathrm{mL}$. Based on these data, the essential oil of Tagetes lucida showed the highest antioxidant activity (CE50=37.9 $\mu \mathrm{g} /$ $\mathrm{mL}$ ), followed by Ocotea sp., and Lippia alba (citral chemotype $($ CE50 values lower than $100 \mu \mathrm{g} / \mathrm{mL})$. Essential oils from Elettaria cardamomum and Lippia alba-carvone (from Tolima) displayed moderate activity, whereas the essential oils isolated from Minthostachys mollis, Lippia alba (carvone chemotype, from Cundinamarca) and Piper sanctifelisis did not show antioxidant capacity, with CE50 values greater than $1000 \mu \mathrm{g} / \mathrm{mL}$.

Medicinal plants and foods from vegetal origin usually contain natural antioxidants that can scavenge free radicals (Miller et al., 2000; Sawai \& Moon, 2000; Bandoniene \& Murkovic, 2002). Antioxidants prevent the radical chain oxidation which destroys membrane integrity, resulting most often in cell lyses. Phenolic compounds such as estragole and eugenol, both found in essential oils presented here are well-known antioxidants (Gil et al., 2000; Soarez et al., 2003; Goupy et al., 2003), whereas some monoterpenes such as $\alpha$-terpinene, $\gamma$-terpinene, and terpinolene only have modest protective action in some models. However, it is important to mention that different components in the same essential oil can generate synergistic interactions (Teissedre \& Waterhouse, 2000).

Finally, although Colombian flora is rich in plants producing essential oils with potential pharmacological properties (Stashenko et al., 2004a), there have been few reports on them. Results provided here showed that there are promissory plant species, some with several chemotypes in Colombian flora, with interesting antioxidant properties, for which more extensive pharmacological activities should be evaluated.

\section{ACKNOWLEDGEMENTS}

Financial support from COLCIENCIAS, Bogotá, Colombia (Grant RC 432-2004), and the University of Cartagena, Cartagena, Colombia, is gratefully appreciated

\section{REFERENCES}

Aburjarai T, Natsheh FM 2003. Plants used in cosmetics. Phytotheraphy Res 17: 987-1000.

Adams RP 1995. Identification of essential oil components by gas chromatography/mass spectrometry. Allured Publishing Corporation, Carol Stream, Illinois, USA.

Ajose FO 2007. Some Nigerian plants of dermatologic importance Int J Dermatol 46: 48-55.

Bandoniene D, Murkovic M 2002. On-line HPLC-DPPH screening method for evaluation of radical scavenging phenols extracted from apples (Malus domestica L.). $J$ Agric Food Chem 50: 2482-2487.

Bounatirou S, Smiti S, Miguel MG, Faleiro L, Rejeb MN, Neffati M, Costa MM, Figueiredo AC, Barroso JG, Pedro LG 2007. Chemical composition, antioxidant and antibacterial activities of the essential oils isolated from Tunisian Thymus capitatus Hoff. Food Chem 105: 146155

Bruni R, Medici A, Andreotti E, Fantin C, Muzzoli M, Dehesa M 2004. Chemical composition and biological activities of Isphingo essential oil, a traditional Ecuadorian spice from Ocotea quixos (Lam.) Kosterm. (Lauraceae) flower calices. Food Chem 85: 415-421. 
Cicció JF 2004. A source of almost pure methyl chavicol: volatile oil from the aerial parts of Tagetes lucida (Asteraceae) cultivated in Costa Rica. Rev Biol Trop 52: 853-857.

Davies NW 1990. Gas chromatographic retention indices of monoterpenes and sesquiterpenes on methyl silicone and Carbowax 20M phases. J Chromatogr A 503: 1-24.

D'Souza P, Deepak M, Rani P, Kadamboor S, Mathew A, Chandrashekar AP, Agarwal A 2002. Brine shrimp lethality assay of Bacopa monnieri. Phytother Res 16: 197-198.

Farzaneh M, Ahmadzadeh M, Hadian J, Tehrani AS 2006. Chemical composition and antifungal activity of the essential oils of three species of Artemisia on some soilborne phytopathogens. Commun Agric Appl Biol Sci 71: 1327-1333.

Finney DJ 1971. Probit Analysis, 3rd ed. Cambridge University Press.

Fisher K, Phillips C 2008. Potential antimicrobial uses of essential oils in food: is citrus the answer? Trends Food Sci Tech 19: 156-164.

Foti MC, Ingold KU 2003. Mechanism of inhibition of lipid peroxidation by gamma-terpinene, an unusual and potentially useful hydrocarbon antioxidant. J Agric Food Chem 51: 2758-2765.

Gil MI, Tomás-Barberán FA, Hess-Pierce B, Holeroft DM, Kadar AA 2000. Antioxidant activity of pomegranate juice and its relationship with phenolic composition and processing. J Agric Food Chem 48: 4581-4589.

Goupy P, Dufour C, Loonis M, Dangles O 2003. Quantitative kinetic analysis of hydrogen transfer reactions from dietary polyphenols to the DPPH radical. J Agric Food Chem 51: 615-622.

Haraguchi H, Ishikawa H, Kubo I 1997. Antioxidative action of diterpenoids from Podocarpus nagi. Planta Med 63: 213-215

Henderson DE, Slickman M 1999. Quantitative HPLC determination of the antioxidant activity of capseicin on the formation of lipid hydroperoxides of linoleic acid: a comparative study against BHT and melatonin. J Agric Food Chem 47: 2563-2570.

Ioannides C, Delaforge M, Parke DV 1981. Safrole: its metabolism, carcinogenicity and interactions with cytochrome P450. Food Cosmet Toxicol 19: 657-666.

Kade IJ, Ibukun EO, Nogueira CW, Da Rocha JB 2008. Sundrying diminishes the antioxidative potentials of leaves of Eugenia uniflora against formation of thiobarbituric acid reactive substances induced in homogenates of rat brain and liver. Exp Toxicol Pathol 60: 365-371.

Kulisic T, Kulisic A, Radonic V, Katalinic M 2004. Use of different methods for testing antioxidative activity of oregano essential oil. Food Chem 85: 633-640.

Li SY, Yu Y, Li SP 2007. Identification of antioxidants in essential oil of radix Angelicae sinensis using HPLC coupled with DAD-MS and ABTS-based assay. J Agric Food Chem 55: 3358-3362.

Magwa ML, Gundidza M, Gweru N, Humphrey G 2006.
Chemical composition and biological activities of essential oil from the leaves of Sesuvium portulacastrum. J Ethnopharmacol 103: 85-89.

Malkinson AM, Koski KM, Evans WA, Festing MF 1997. Butylated hydroxytoluene exposure is necessary to induce lung tumors in BALB mice treated with 3-methylcholanthrene. Cancer Res 57: 2832-2834.

Marongiu B, Piras A, Porcedda S 2004. Comparative analysis of the oil and supercritical $\mathrm{CO}_{2}$ extract of Elettaria cardamomum (L.) Maton. J Agric Food Chem 52: 62786282

Massele AY, Nshimo CM 1995. Brine shrimp bioassay for biological activity of medicinal plants used in traditional medicines in Tanzania. East Afr Med J 72: 661-663.

Medina-Holguín AL, Holguín FO, Micheletto S, Goehle S, Simon JA, O'Connell MA 2008. Chemotypic variation of essential oils in the medicinal plant, Anemopsis californica. Phytochemistry 69: 919-27.

Miller E, Rigelhof F, Marquart L, Pakash A, Kante RM 2000. Antioxidant content of whole grain breakfast cereals, fruits and vegetables. J Amer Coll Nutr 19: 312S-319S.

Monteiro MV, de Melo Leite AK, Bertini LM, de Morais SM, Nunes-Pinheiro DC 2007. Topical anti-inflammatory, gastroprotective and antioxidant effects of the essential oil of Lippia sidoides Cham. leaves. J Ethnopharmacol 111: 378-382.

Natsch A, Wasescha M 2007. Fragrance raw materials and essential oils can reduce prostaglandin E2 formation in keratinocytes and reconstituted human epidermis. Int $J$ Cosmet Sci 29: 369-376.

Oliveira D, Leitao G, Santos S, Bizzo DP, Alviano CS, Alviano DS 2006. Ethnopharmacological study of two Lippia species from Oriximiná, Brazil. J Ethnopharm 108: 103108.

Pokorny J, Yanishlieva N, Gordon M 2001. Antioxidants in Food. Woodhead Publishing Limited, CRC, Press, Cambridge.

Ravishankar S, Zhu L, Law B, Joens L, Friedman M 2008. Plant-derived compounds inactivate antibiotic-resistant Campylobacter jejuni strains. J Food Prot 71: 11451149.

Ruberto G, Baratta MT, Deans SG, Dorman HJ 2000. Antioxidant and antimicrobial activity of Foeniculum vulgare and Crithmum maritimum essential oils. Planta Med 66: 687693.

Sawai Y, Moon JH 2000. NMR analytical approach to clarify the molecular mechanisms of the antioxidative and radical-scavenging activities of antioxidants in tea using 1,1-diphenyl-2-picrylhydrazyl. J Agric Food Chem 48: 6247-6253.

Sacchetti G, Maietti S, Muzzoli M, Scaglianti M, Manfredini S, Radice M, Bruni R 2005. Comparative evaluation of 11 essential oils of different origin as functional antioxidants, antiradicals and antimicrobials in foods. Food Chem 91: 621-632.

Safaei-Ghomi J, Ebrahimabadi AH, Djafari-Bidgoli Z, Batooli $\mathrm{H}$ 2009. GC/MS analysis and in vitro antioxidant 
activity of essential oil and methanol extracts of Thymus caramanicus Jalas and its main constituent carvacrol. Food Chem 115: 1524-1528.

Sharififar F, Moshafi H, Mansouri SH, Khodashenas M, Khoshnoodi M 2007. In vitro evaluation of antibacterial and antioxidant activities of the essential oil and methanol extract of endemic Zataria multiflora Boiss. Food Control 18: 800-805.

Soarez DG, Andreazza AC, Salvador M 2003. Sequestering ability of butylated hydroxytoluene, propyl gallate, resveratrol, and vitamins $\mathrm{C}$ and $\mathrm{E}$ against $\mathrm{ABTS}$, DPPH, and hydroxyl free radicals in chemical and biological systems. Agric Food Chem 51: 1077-1080.

Stashenko EE, Jaramillo BE, Martínez JR. 2004a. Comparison of different extraction methods for the analysis of volatile secondary metabolites of Lippia alba (Mill.) N.E. Brown, grown in Colombia, and evaluation of its in vitro antioxidant activity. J Chromatogr A 1025: 93-103.

Stashenko EE, Jaramillo BE, Martínez JR 2004b. Analysis of volatile secondary metabolites from Colombian Xylopia aromatica (Lamarck) by different extraction and headspace methods and gas chromatography. $J$ Chromatogr A 1025: 105-113.

Tabanca N, Ma G, Pasco DS, Bedir E, Kirimer N, Baser KH, Khan IA, Khan SI 2007. Effect of essential oils and isolated compounds from Pimpinella species on NFkappaB: a target for antiinflammatory therapy. Phytother Res 21: 741-745.

Teissedre PL, Waterhouse AL 2000. Inhibition of oxidation of human low-density lipoproteins by phenolic substances in different essential oils varieties. J Agric Food Chem 48: 3801-3805.

Tekeoglu I, Dogan A, Ediz L, Budancamanak M, Demirel A 2007. Effects of hymoquinone (volatile oil of black cumin) on rheumatoid arthritis in rat models. Phytother Res 21: 895-897.

Viana GS, do Vale TG, Silva CM, Matos FJ 2000. Anticonvulsant activity of essential oils and active principles from chemotypes of Lippia alba (Mill.) N.E. Brown. Biol Pharm Bull 23: 1314-1317.

Weiss EA 1997. Essential oil crops, Oxford University Press, London.

Yildirim A, Mavi A, Oktay M, Kara AA, Algur OF, Bilaloglu V 2000. Comparison of antioxidant and antimicrobial activities of tilia (Tilia argentea Desf Ex DC), sage (Salvia triloba L.), and black tea (Camellia sinensis) extracts. J Agric Food Chem 48: 5030-5034.

Zhang Z, Chang Q, Zhu M, Huang Y, Ho WK, Chen Z 2001. Characterization of antioxidants present in hawthorn fruits. J Nutr Biochem 12: 144-152.

Zoghbi MGB, Andrade EHA, Santos AS, Silva MHL, Maia JGS 1998. Essential oils of Lippia alba (Mill.) NEBr growing wild in the Brazilian Amazon. Flavour Fragr J 13: 4748 . 